\title{
The effect of composts from potato pulp and municipal sewage sludge for changes of microelements in the soil during incubation
}

\author{
Ewa Krzywy-Gawrońska, Monika Rozmarynowska \\ University Agricultural, Department of Environmental Chemistry, ul. Stowackiego 17, 71-434 Szczecin, Poland, \\ e-mail: chemrol@agro.ar.szczecin.pl
}

\begin{abstract}
The total and soluble content of microelements in the soil was described in the laboratory experiment. The soil was incubated with three doses of composts with a participation of municipal sewage sludge and potato pulp. The obtained results of the experiment pointed that all the composts increased an average total content and the forms soluble in $1 \mathrm{M} \mathrm{HCl}$ of microelements in the soil in comparison with the control. In the majority of the variants, the composts made with the $70 \%$ participation of municipal sewage sludge and $30 \%$ addition of straw or sawdust caused an increase of the content of the analyzed elements in the soil than the composts with the $70 \%$ participation of potato pulp and $30 \%$ addition of straw or sawdust. The differences are connected with a higher content of microelements, which were put in the soil, with the composts with the $70 \%$ participation of municipal sewage sludge and $30 \%$ addition of straw or sawdust. There are no differences in the formation of the content of microelements in the soil, which were depended on the type of the structural - formative component during the production of composts. The quantity of the composts' dose had an influence on the formation of the participation of the soluble form of microelements in the total content in the soil. The participation of the soluble form of cadmium, cooper, manganese and nickel in the total content in the soil increased along with increasing the dose of composts. The content of the total forms in the soil incubated with the composts included in the standard for the light soils.
\end{abstract}

Keywords: potato pulp, municipal sewage sludge, composts, soil, microelementsl.

Presented at VII Conference Wasteless Technologies and Waste Management in Chemical Industry and Agriculture, Międzyzdroje, 12 - 15 June, 2007.

\section{INTRODUCTION}

The latest deeds, which involve the environment protection, have imposed an obligation of developing or utilizing the produced wastes on the producers or importers.

Until recently the wastes of the potato industry (potato pulp, stock distillery) were used as the fodder components in the animals' nutrition. There has been a problem with their development owing to the reduction of the number of animal farm. The Existing experiments show that potato pulp is charactering an acid $\mathrm{pH}$, not much amount of dry mass and the visibly larger content of potassium in relation to nitrogen and phosphorus $^{7,8,10 .}$

According to Baran ${ }^{1,2}$, Czekała ${ }^{3}$, Krzywy et al. ${ }^{5,6}$, Mazur ${ }^{9}$, Oleszkiewicz $^{11}$, Urbaniak ${ }^{14}$ and Wołoszyk ${ }^{15}$ sewage sludge composts contain in their composition the organic mass and the high content of some ingredients for the plants, which points to the possibility of using them to fertilize soils. The experiments carried out so far indicate that not each of the municipal sewage sludge can be used for the purpose of fertilization, because they can include the excessive amount of heavy metals, the pathogenic microorganisms and the parasites. According to standing legislation, before putting the municipal sewage sludge into the soil, it should be submitted to stabilization and a hygienic process in order to decrease the heavy metals concentration, as well the pathogenic microorganisms to the standards which are included in the Minister's Environments $\operatorname{Order}^{13}$. One of the most frequently used ways of the utilization and hygienic of sewage sludge composts is composting.

The aim of the study was to term the influence of composts from potato pulp and the municipal sewage sludge with the participation of the structural - formative components (rye straw or sawdust from the conifers) for the changes of the total forms and the forms soluble in $1 \mathrm{M} \mathrm{HCl}$ of cadmium, cooper, manganese, nickel, zinc and lead at the time of incubation of the composts with the soil.

\section{MATERIAL AND METHODS}

The soil from the Ap level of the production field of the Agriculture Experimental Station in Lipnik near Stargard Szczeciński, was used for the studies. The soil was numbered among the brown incomplete soil of the mechanical composition of light loam. The soil was numbered to the complex of rye good of quality class IV a for the sake of agriculture usefulness. The more important chemical features of the soil used in the experiment were presented in Table 1.

The data in Table 1 show that the soil, which was taken for the experiment, was characterized by the lightly acid $\mathrm{pH}$, the content of organic $\mathrm{C}$ amounted to $6,30 \mathrm{~g} \cdot \mathrm{kg}^{-1}$, the total nitrogen $0,70 \mathrm{~g}^{\mathrm{kg}} \mathrm{kg}^{-1}$, value of the $\mathrm{C}: \mathrm{N}$ relation amounted to 9,07 . The total content of phosphorus amounted to 1,62 , potassium 5,30, calcium 1,04, magnesium $0,28 \mathrm{~g} \cdot \mathrm{kg}^{-1}$. The abundance in the available magne-

Table 1. The content of the macroelements in the soil used in the experiment

\begin{tabular}{|c|c|c|c|c|c|c|c|c|c|c|c|}
\hline \multirow[t]{2}{*}{$\mathrm{pH}_{\mathrm{KCl}}$} & \multirow{2}{*}{$\begin{array}{c}\text { C org } \\
\left(\mathrm{g} \cdot \mathrm{kg}^{-1}\right)\end{array}$} & \multicolumn{6}{|c|}{ Total forms (g. $\left.\mathrm{kg}^{-1} \mathrm{~d} . \mathrm{m}.\right)$} & \multicolumn{3}{|c|}{$\begin{array}{c}\text { Available forms } \\
\text { (mg.kg-1 d.m.) }\end{array}$} & \multirow{2}{*}{$\begin{array}{c}\mathrm{S}-\mathrm{SO}_{4} \\
\left(\mathrm{mg} \cdot \mathrm{kg}^{-1} \mathrm{~d} \cdot \mathrm{m} .\right)\end{array}$} \\
\hline & & $\mathbf{N}$ & $\mathbf{P}$ & $\mathbf{K}$ & $\mathrm{Ca}$ & Mg & $\mathbf{S}$ & $\mathbf{P}$ & $\mathbf{K}$ & Mg & \\
\hline 5.70 & 6.30 & 0.70 & 1.62 & 5.30 & 1.04 & 0.28 & 0.20 & 94.0 & 109.1 & 29.0 & 11.50 \\
\hline
\end{tabular}


sium was low, the available phosphorus - high, and available potassium - mean. The total content of heavy metals was: $\mathrm{Cd}-0,12, \mathrm{Cu}-5,50, \mathrm{Mn}-140, \mathrm{Ni}-4,60, \mathrm{~Pb}-19,8$, a $\mathrm{Zn}-35,8 \mathrm{mg} \cdot \mathrm{kg}^{-1} \mathrm{~d} . \mathrm{m}$. in the soil. These contents were within the natural limit for the light soil ${ }^{4}$.

The composts were made from municipal sewage sludge and potato pulp with an addition of rye straw and sawdust from the conifers in March 2002.

The composition of the composts in converting to dry mass was (the numbers in parenthesis mean the percentage participation of the components in the composts) as follows: Compost A - potato pulp (35\%), municipal sewage sludge $(35 \%)$ and rye straw $(30 \%)$, Compost B potato pulp (35\%), municipal sewage sludge (35\%) and sawdust from the conifers $(30 \%)$, Compost $\mathrm{C}$ - potato pulp $(70 \%)$, and rye straw $(30 \%)$, Compost $\mathrm{D}$ - potato pulp $(70 \%)$, and sawdust from the conifers $(30 \%)$, Compost E - municipal sewage sludge (70\%), rye straw (30\%), Compost F - municipal sewage sludge (70\%), sawdust from the conifers $(30 \%)$.

The experiment included the study, which was concerned with the influence of the composts from potato pulp and municipal sewage sludge for some indications of the fertility of the soil. In the pattern of the experiment (Table 3) there were taken into consideration the four types of composts and the control variant, three doses of composts and four time limits of the marks of the indicators of the fertility of the soil - after 30, 60, 90 and 120 days of the incubation of the soil with the composts.

The soil was sifted on the sieve, which was $5 \mathrm{~mm}$ in diameter of the mesh, in order to undergo decontamination. Afterwards, the soil was weighted at $3 \mathrm{~kg}$ and then was mixed with the appropriate types and doses of composts. After mixing accurately the composts with the soil, the whole was poured into the plastic columns, $10 \mathrm{~cm}$ in diameter.

The chemical characterization of composts after disintegration for nine months was presented in Table 2.

The quantity of the doses of composts was established on the base of the content of nitrogen in them. The first dose corresponded to $100 \mathrm{~kg} \cdot \mathrm{ha}$, that was the $0,1 \mathrm{~N} \cdot$ column, the second dose corresponded to $200 \mathrm{~kg} \mathrm{~N} \cdot \mathrm{ha}$, that was the $0,2 \mathrm{~g} \mathrm{~N} \cdot$ column and the third dose corresponded to $300 \mathrm{~kg}$ $\mathrm{N} \cdot$ ha, that was the $0,3 \mathrm{~g} \mathrm{~N} \cdot$ column.

The experiment was carried out in three repetitions. The columns with the soil were placed in the room of the Department of Environmental Chemistry. During the experiment the humidity of the soil was being kept on the $60 \%$ level of the full water humidity. The soil in the columns was being sprinkled with the redistilled water.

The samples of the soil were taken for the laboratory tests. These samples were taken from the individual repetitions of each fertilizer object after 30, 60, 90 and 120 days of the incubation of the soil with the composts. After drying, the samples of the soil from three repetitions were mixed. In this way the average object samples were made.

The total content of $\mathrm{Cd}, \mathrm{Cu} . \mathrm{Mn}, \mathrm{Ni}, \mathrm{Pb}$ and $\mathrm{Zn}$ as well the soluble forms of these elements in $1 \mathrm{M} \mathrm{HCl}$ were marked in the average samples. There were used the methods of Ostrowska ${ }^{12}$ in the experiment.

\section{RESULTS AND DISCUSSION}

Three factors were taken into consideration in the pattern of this experiment. The types of the composts were the first factor (6), the doses were the second one (3), and the time limit of the marks - the third one (4).

The content of the total forms of cadmium, copper, manganese, nickel, lead and zinc and the forms soluble in $1 \mathrm{M} \mathrm{HCl}$ were marked in the incubated soil for 120 days, with composts every 30 days. The average contents, depending on the type of the composts, doses and the time limit of the marks (the time of incubation) were presented in the discussion on the results in Table 3.

The fertilized soil of the composts with the $70 \%$ participation of municipal sewage sludge included the most total forms of cadmium, copper, manganese, nickel, lead and zinc, and next - soil with the composts from potato pulp (35\%) and municipal sewage sludge (35\%) (Table 3 ). The fertilized soil of the composts with $70 \%$ participation of potato pulp included the least total forms. The differences in the content of the total forms of cadmium,

Table 2. The chemical characterization of the composts before putting them into the columns with the soil

\begin{tabular}{|c|c|c|c|c|c|c|}
\hline \multirow{2}{*}{ Ingredient } & \multicolumn{6}{|c|}{ Type of compost } \\
\hline & $\mathbf{A}$ & B & C & D & $\mathbf{E}$ & $\mathbf{F}$ \\
\hline $\mathrm{PH}$ & 5,8 & 5,7 & 4,5 & 4,3 & 8,4 & 8,3 \\
\hline \multicolumn{7}{|c|}{ total content (g. $\mathrm{kg}^{-1}$ d.m.) } \\
\hline \multicolumn{7}{|c|}{ total content (mg. $\left.\mathrm{kg}^{-1} \mathrm{~d} . \mathrm{m}.\right)$} \\
\hline $\begin{array}{l}\mathrm{Cd} \\
\mathrm{Cu} \\
\mathrm{Mn} \\
\mathrm{Ni} \\
\mathrm{Pb} \\
\mathrm{Zn}\end{array}$ & $\begin{array}{c}1,15 \\
45,6 \\
110,7 \\
10,3 \\
32,0 \\
172,3\end{array}$ & $\begin{array}{c}1,10 \\
46,2 \\
105,7 \\
11,9 \\
31,2 \\
169\end{array}$ & $\begin{array}{c}0,03 \\
7,12 \\
21,0 \\
1,42 \\
4,2 \\
18,2\end{array}$ & $\begin{array}{c}0,04 \\
6,54 \\
11,2 \\
1,82 \\
6,83 \\
10,2 \\
\end{array}$ & $\begin{array}{c}2,28 \\
91,5 \\
258,7 \\
16,5 \\
64,3 \\
290,3\end{array}$ & $\begin{array}{r}2,40 \\
76,0 \\
218,3 \\
17,3 \\
65,6 \\
317,1\end{array}$ \\
\hline
\end{tabular}

*Explanation of the composition of the composts when converting into dry mass:

Compost A - potato pulp (35\%), municipal sewage sludge (35\%) and rye straw (30\%), Compost B - potato pulp (35\%), municipal sewage sludge $(35 \%)$ and sawdust from the conifers $(30 \%)$, Compost $C$ - potato pulp $(70 \%)$, and rye straw $(30 \%)$, Compost D - potato pulp $(70 \%)$, and sawdust from the conifers (30\%), Compost E - municipal sewage sludge (70\%) and rye straw (30\%), Compost F - municipal sewage sludge $(70 \%)$ and sawdust from the conifers $(30 \%)$ 
copper, manganese, nickel, lead and zinc between the soil with the composts with the $70 \%$ participation of municipal sewage sludge and the remaining objects with the composts, were essential (table 3 ).

Doubling and tripling the doses of the composts increased the contents of the total forms of cadmium, manganese, nickel and zinc in the soil. The content of the total forms of copper and lead in the soil increased essentially only under the influence of the double composts' dose in relation to the single dose (Table 3 ).

The content of the total forms of cadmium, copper, nickel, lead and zinc did not undergo any essential changes during the distribution of the composts' mass in the soil. There was only an increasing content of the total form of manganese in the soil between the first (30 days) and the last (120) time limit of taking the sample (Table 3).

Taking into consideration the effect of the structural formative components in the form of rye straw or sawdust from the conifers, which had been put into the compost's mass, on the content of the total forms of cadmium, copper, manganese, nickel, lead and zinc in soil, it could be said that it was placed in the limits of the experimental error.

The fertilized soils of the composts visibly included more forms soluble in $1 \mathrm{M} \mathrm{HCl}$ of cadmium, copper, manganese, nickel, lead and zinc than the soil from the control object (Table 3 ).

The fertilized soil of the composts with the $70 \%$ participation of municipal sewage sludge included the biggest number of the forms soluble in $1 \mathrm{M} \mathrm{HCl}$ of cadmium, copper and zinc. The content of the soluble forms of cadmium was the same in the fertilized soil of the composts from potato pulp (35\%) and municipal sewage sludge $(35 \%)$ as well as with composts with the $70 \%$ participation of potato pulp. The soil with the composts with the $70 \%$ participation of potato pulp included the smallest number of forms soluble in $1 \mathrm{M} \mathrm{HCl}$ of cooper and zinc. The differences in the effect between the composts with the $70 \%$ participation of municipal sewage sludge and the composts with the $70 \%$ participation of potato pulp on the content of the forms soluble in $1 \mathrm{M} \mathrm{HCl}$ of cadmium, copper and zinc in the soil were essential (table 3). However, the differences in the influence of the composts with the $70 \%$ participation of potato pulp and the composts with potato pulp (35\%) and municipal sewage sludge on the content of the forms soluble in $1 \mathrm{M} \mathrm{HCl}$ of cadmium and zinc in the soil were confined in the limits of the experimental error (Table 3 ).

The fertilized soil of composts with $70 \%$ participation of potato pulp included the most forms soluble in $1 \mathrm{M}$ $\mathrm{HCl}$ of manganese, nickel and lead. Actually, fewer forms soluble in $1 \mathrm{M} \mathrm{HCl}$ of nickel and lead were present in the fertilized soil of the composts with the $70 \%$ participation of municipal sewage sludge. The fertilized soil of the composts with potato pulp $(35 \%)$ and municipal sewage sludge $(35 \%)$ included the least forms soluble in $1 \mathrm{M} \mathrm{HCl}$ of nickel and lead. These differences were essential.

The content of the form soluble in $1 \mathrm{M} \mathrm{HCl}$ of manganese in the soil was the least after the composts with the $70 \%$ participation of municipal sewage sludge were introduced into it. The differences in the influence between the composts with the $70 \%$ participation of municipal sewage sludge and the composts from potato pulp (35\%) and municipal sewage sludge $(35 \%)$ on the content of the forms soluble in $1 \mathrm{M} \mathrm{HCl}$ of manganese in the soil were included within the limits of the experimental error (Table 3 ).

Doubling and tripling the doses of the composts had a significant influence on the increasing of the content of the forms soluble in $1 \mathrm{M} \mathrm{HCl}$ of cadmium, cooper, manganese, nickel and lead (Table 3 ).

The period of the disintegration of compost's mass in the soil did not affect the formation of the content of the forms soluble in $1 \mathrm{M} \mathrm{HCl}$ of cooper, manganese, nickel and zinc in the soil. The content of the forms soluble in $1 \mathrm{M} \mathrm{HCl}$ of cadmium increased during the disintegration of the compost's mass (since the 90th day). The content of the forms soluble in $1 \mathrm{M} \mathrm{HCl}$ of lead in the soil decreased slightly after 60 days. After 90 days that content increased indeed, and after 120 days of that disintegration the content decreased slightly (Table 3 ).

The structural - formative components in the form of rye straw or sawdust from the conifers, which had been put into the composts, did not affect the formation of the content of the forms soluble in $1 \mathrm{M} \mathrm{HCl}$ of cadmium,

Table 3. The total content and the forms soluble in $1 \mathrm{M} \mathrm{HCl}$ of cadmium, copper, nickel, lead and zinc in the soil depending on the type and dose as well as the time of the incubation of the composts with the soil

\begin{tabular}{|c|c|c|c|c|c|c|c|c|c|c|c|c|}
\hline \multirow{2}{*}{ Type of compost } & $\mathrm{Cd}$ & $\mathrm{Cu}$ & $\mathrm{Mn}$ & $\mathrm{Ni}$ & $\mathrm{Pb}$ & $\mathrm{Zn}$ & $\mathrm{Cd}$ & $\mathrm{Cu}$ & $\mathrm{Mn}$ & $\mathrm{Ni}$ & $\mathrm{Pb}$ & $\mathrm{Zn}$ \\
\hline & \multicolumn{6}{|c|}{ The total content in $\mathrm{mg} \cdot \mathrm{kg}^{-1} \mathrm{~d} . \mathrm{m}$. } & \multicolumn{6}{|c|}{ The content of forms soluble in $1 \mathrm{M} \mathrm{HCl} \mathrm{mg} \cdot \mathrm{kg}^{-1} \mathrm{~d} \cdot \mathrm{m}$. } \\
\hline Compost A & 0,14 & 5,84 & 167 & 4,88 & 6,38 & 42,5 & 0,09 & 2,59 & 45,4 & 2,07 & 2,81 & 20,4 \\
\hline Compost B & 0,14 & 5,63 & 168 & 4,84 & 6,25 & 42,6 & 0,09 & 2,55 & 46,1 & 2,07 & 2,86 & 21,2 \\
\hline Compost C & 0,13 & 5,43 & 145 & 4,64 & 5,84 & 38,95 & 0,09 & 2,25 & 52,7 & 2,43 & 2,70 & 18,9 \\
\hline Compost D & 0,13 & 5,50 & 147 & 4,65 & 5,85 & 38.9 & 0,09 & 2,26 & 53,3 & 2,43 & 2,72 & 18,7 \\
\hline Compost E & 0,18 & 6,06 & 171 & 5,10 & 6,94 & 45,5 & 0,10 & 3,22 & 43,7 & 2,29 & 2,95 & 22,9 \\
\hline Compost F & 0,18 & 6,21 & 172 & 5,00 & 6,91 & 45,1 & 0,11 & 3,26 & 44,2 & 2,29 & 2,98 & 22,8 \\
\hline NIR $_{0,05}$ LSD $_{0,05}$ & 0,016 & 0,164 & 3,67 & 0,070 & 0,206 & 1,31 & 0,012 & 0,162 & 2,71 & 0,049 & 0,091 & 3,211 \\
\hline Dose I & 0,14 & 5,72 & 158 & 4,78 & 6,25 & 41,6 & 0,09 & 2,54 & 42,7 & 2,15 & 2,74 & 19,4 \\
\hline Dose II & 0,15 & 5,80 & 162 & 4,85 & 6,35 & 42,3 & 0,10 & 2,66 & 48,7 & 2,28 & 2,84 & 21,0 \\
\hline Dose III & 0,17 & 5,82 & 165 & 4,90 & 6,46 & 43,1 & 0,11 & 2,87 & 51,4 & 2,35 & 2,96 & 22,1 \\
\hline NIR $_{0,05}$ LSD $_{0,05}$ & 0,009 & 0,151 & 2,11 & 0,04 & 0,118 & 0,755 & 0,007 & 0,102 & 1,562 & 0,022 & 0,052 & 1,846 \\
\hline Deadline 1. & 0,16 & 5,77 & 162 & 4,83 & 6,30 & 42,2 & 0,10 & 2,67 & 46,7 & 2,26 & 2,84 & 20,6 \\
\hline Deadline 2. & 0,16 & 5,75 & 160 & 4,85 & 6,36 & 42,3 & 0,10 & 2,71 & 47,7 & 2,26 & 2,82 & 20,6 \\
\hline Deadline 3. & 0,16 & 5,80 & 162,2 & 4,84 & 6,40 & 42,4 & 0,10 & 2,69 & 47,9 & 2,25 & 2,87 & 21,2 \\
\hline Deadline 4. & 0,16 & 5,80 & 162,2 & 4,87 & 6,38 & 42,5 & 0,09 & 2,70 & 48,1 & 2,29 & 2,83 & 20,7 \\
\hline NIR $_{0,05}$ LSD $_{0,05}$ & r.n. & r.n. & 2,63 & r.n. & r.n. & r.n & 0,009 & r.n. & r.n. & r.n. & 0,066 & r.n. \\
\hline Mean & 0,15 & 5,78 & 161,6 & 4,85 & 6,23 & 42,3 & 0,09 & 2,69 & 47,6 & 2,26 & 2,84 & 20,8 \\
\hline Control & 0,13 & 5,31 & 161 & 4,60 & 5,83 & 38,9 & 0,08 & 1,75 & 38,2 & 1,57 & 2,68 & 15,4 \\
\hline
\end{tabular}

* Explanations of the composition of the composts as in Table 1 
Table 4. Average participation of the forms of trace elements soluble in $1 \mathrm{M} \mathrm{HCl}$ in the soil in the total content during the incubation with the composts, depending on the type and the dose of the compost (\%)

\begin{tabular}{|c|c|c|c|c|c|c|c|c|c|}
\hline \multirow{2}{*}{ Element } & \multicolumn{6}{|c|}{ Type of compost } & \multicolumn{3}{|c|}{ Doses } \\
\hline & $\mathbf{A}$ & B & $\mathbf{C}$ & D & $\mathbf{E}$ & $\mathbf{F}$ & I & II & III \\
\hline $\mathrm{Cd}$ & 64,3 & 64,3 & 69,2 & 69,2 & 55,5 & 61,1 & 61,53 & 62,20 & 64,70 \\
\hline $\mathrm{Cu}$ & 44,3 & 45,3 & 41,4 & 41,1 & 53,1 & 52,2 & 44,40 & 45,86 & 49,48 \\
\hline $\mathrm{Ni}$ & 42,2 & 42,8 & 52,2 & 52,3 & 44,9 & 45,8 & 44,97 & 47,01 & 48,05 \\
\hline $\mathrm{Pb}$ & 44,0 & 45,7 & 49,4 & 49,9 & 42,5 & 43,1 & 47,65 & 46,74 & 48,18 \\
\hline $\mathrm{Zn}$ & 48,0 & 49,8 & 48,7 & 48,3 & 50,3 & 50,5 & 47,38 & 49,78 & 50,15 \\
\hline
\end{tabular}

* Explanations of the composition of the composts as in Table 2

cooper, manganese, nickel, zinc and lead in the soil in the single majority of the experiment's object (Table 3).

The participation of the forms soluble in $1 \mathrm{M} \mathrm{HCl}$ in the total content of the trace elements in the soil, depending on the compost's type and the quantity of dose, was presented in the relative number (the total content $=100 \%$ ) in Table 4 .

The quantity of the composts dose had an influence on the formation of the participation of the soluble form of trace elements in the total content in the soil (Table 4). The participation of the soluble form of cadmium, cooper, manganese and nickel in the total content in the soil was increasing along with the height of composts' dose. The least participation of the soluble form in the total content was in the case of lead, however, by the second dose of the composts and the most participation by that composts' dose was observed in the case of zinc.

The structural - formative components in the form of rye straw or sawdust from the conifers, which had been put into the composts, did not affect the formation of the content of the forms soluble in $1 \mathrm{M} \mathrm{HCl}$ of cadmium, cooper, manganese, nickel, zinc and lead in the soil in the majority of the experiment's object (Table 4).

The composts, which were used in this experiment, affected in a different way the percentage of the participation of the forms soluble in $1 \mathrm{M} \mathrm{HCl}$ of heavy metals in the soil in relation to the total forms (Table 4).

The fluctuation and the mean percentage participation of the forms soluble in $1 \mathrm{M} \mathrm{HCl}$ of heavy metals in the soil in relation to the total forms were presented as follows:

- for cadmium from $55,55 \%$ to $69,23 \%$ (mean $63,94 \%$ ),

- for copper from $41,10 \%$ to $53,30 \%$ (mean $45,61 \%$ ),

- for manganese from $25,43 \%$ to $36,42 \%$ (mean $29,75 \%)$,

- for nickel from $42,24 \%$ to $52,82 \%$ (mean 46,85 ),

- for lead from $40,94 \%$ to $59,81 \%$ (mean $48,42 \%$ ),

- for zinc from $47,10 \%$ to $51,42 \%$ (mean $49,43 \%$ ).

The combination shows that owing to the influence of using the composts there were on average the most forms soluble in $1 \mathrm{M} \mathrm{HCl}$ of cadmium $(63,9 \%)$ in the soil, and the least - manganese $(29,7 \%)$ in relation to the total forms. An average percentage participation of the forms soluble in $1 \mathrm{M} \mathrm{HCl}$ of cooper, nickel, lead and zinc in relation to the total forms amounted to $45,3 \%$ for copper, $46,7 \%$ for nickel, $45,8 \%$ for lead and 49,3\% for zinc. An average difference of the percentage participation of forms soluble in $1 \mathrm{M} \mathrm{HCl}$ of these heavy metals in relation to the total forms widened to an insignificant extent.

The soil, in which the composts with the $70 \%$ percentage of potato pulp had been put, was characterized by the biggest percentage participation of the forms soluble in 1
$\mathrm{M} \mathrm{HCl}$ of cadmium, manganese, nickel and lead in relation to the total forms.

The soil, in which the composts with the $70 \%$ percentage of municipal sewage sludge had been put, was characterized by the smallest percentage participation of the forms soluble in $1 \mathrm{M} \mathrm{HCl}$ of cadmium, manganese and lead. The percentage participation of the forms soluble in $1 \mathrm{M} \mathrm{HCl}$ of cooper in relation to total forms in the soil was the biggest under the influence of the composts with the $70 \%$ participation of municipal sewage sludge, and the smallest one was under the influence of the composts with the $70 \%$ participation of potato pulp.

Doubling the doses of the composts caused on average an increase of the participation of the forms soluble in 1 $\mathrm{M} \mathrm{HCl}$ of cooper, manganese, nickel, lead and zinc. The differences between the influence of the individual doses were within the limits of the experimental error. The percentage participation of cadmium decreased in relation to a single and double dose under the influence of the double dose of the composts.

\section{CONCLUSIONS}

1. The fertilized soil of the composts with the $70 \%$ participation of the municipal sewage sludge included the most total forms of cadmium, copper, manganese, nickel, lead and zinc. Next there was the soil with the composts with potato pulp (70\%) and rye straw or sawdust from the conifers $(30 \%)$.

2. Doubling and tripling the composts' doses increased the content of total forms of cadmium, manganese, nickel and zinc in the soil. The content of the total forms of copper and lead in the soil increased essentially under the influence of only the triple composts' dose in relation to the single dose.

3. The structural - formative components in the form of rye straw and sawdust from the conifers, which had been put in the composts, did not become different from the content of the forms soluble in $1 \mathrm{M} \mathrm{HCl}$ of cadmium, copper, manganese, nickel, lead and zinc in the soil, predominantly of the variants.

4. Because of the use of the composts there were on average the most forms soluble in $1 \mathrm{M} \mathrm{HCl}$ of cadmium $(63,9 \%)$ in the soil, and the least manganese $(29,7 \%)$ in relation to the total forms. The participation of the soluble forms in the total content of the remaining trace elements $\mathrm{Cu}, \mathrm{Ni}, \mathrm{Pb}$ and $\mathrm{Zn}$ fluctuated from 45,5 to $49,4 \%$.

5 . The quantity of the compost's dose had an influence on the formation of the participation of the soluble content of trace elements in the total content in the soil. The participation of the soluble form of cadmium, cooper, manganese and nickel in the total content in the soil increased along with the height of the compost's dose. The 
least participation of the soluble form in the total content was affirmed in the case of lead by the second composts' dose $(46,7 \%)$. The highest participation of the same dose was noted in the case of zinc $(49,8 \%)$.

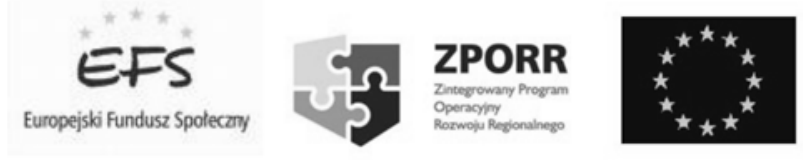

The author of this publication is a grant holder within the confines of the project „Structure of the scientific potential of the region in the fundamental area for its development - scholarships for the students of Agricultural University in Szczecin, who are preparing research in the field of the agriculture, fishery, agricultural - foodstuffs industry, waste disposal" and which is financed by European Social Fund and National Budget within the confines of the Integrated Program Operational Regional Development.

\section{LITERATURE CITED}

(1) Baran S., Turski R.: Wybrane zagadnienia z utylizacji i Wydawnictwo AR Lublin, 1999, ss. 336.

(2) Baran S.: Zasoby i gospodarka odpadami organicznymi w Polsce. Wybrane aspekty zagospodarowania odpadów organicznych a produkcja biomasy wierzby energetycznej. Wydaw. Rzeszów, 2005, 17 - 40.

(3) Czekała J.: Osady ściekowe źródłem materii organicznej i składników pokarmowych. Fol. Univ. Stetnensis, 200, Agricultura, 1999, 77: 33 - 38.

(4) Kabata-Pendias A., Piotrowska M.: Pierwiastki śladowe jako kryterium rolniczej przydatności odpadów. Wydaw. IUNG. Puławy Seria P, 1987, (33).

(5) Krzywy E., Wołoszyk Cz., Iżewska A.: Wartość nawozowa komunalnych osadów ściekowych. PTIE Oddział Szczeciński: 2000, ss 62.

(6) Krzywy E., Wołoszyk Cz., Iżewska A.: Produkcja i rolnicze wykorzystanie kompostów $\mathrm{z}$ osadu ściekowego $\mathrm{z}$ dodatkiem różnych komponentów. PTIE Oddział Szczeciński, 2002, ss. 39.

(7) Krzywy E., Krzywy J.: Skład chemiczny odpadów ziemniaczanych i osadów ściekowych $\mathrm{w}$ aspekcie możliwości wykorzystania ich do celów nawozowych. Zesz. Probl. Post. Nauk Rol. 2003, 494: 233 - 239.

(8) Krzywy E., Krzywy J.: Optymalizacja właściwości nawozowych odpadów pochodzenia organicznego w wyniku ich kompostowania. Wybrane aspekty zagospodarowania odpadów organicznych a produkcja biomasy wierzby energetycznej. Wydaw. Rzeszów: 2005, 41 - 62.

(9) Mazur T.: Rozważania o wartości nawozowej osadów ściekowych. Zesz. Prob. Post. Nauk. Rol., 1996, 437: 13 - 22.

(10) Mazur T., Krzywy E., Mazur Z., Wojtas A.: Wpływ kompostów otrzymanych na bazie wycierki ziemniaczanej na plon i cechy morfologiczne pszenżyta i rzepaku. Zesz. Probl. Post. Nauk Rol., 2004, 499: 230 - 239.

(11) Oleszkiewicz J.: Gospodarka osadami ściekowymi. Poradnik decydenta. LEM s.c. Kraków, 1998, ss. 284.

(12) Ostrowska A., Gawliński S., Szczubiałka Z.: Metody analizy i oceny właściwości gleb i roślin. Instytut Ochrony Środowiska, Warszawa, 1991, ss. 364.

(13) Rozporządzenie Ministra Rolnictwa i rozwoju Wsi z dnia 19 października $\mathbf{2 0 0 4}$ r. w sprawie wykonywania niektórych przepisów ustawy o nawozach i nawożeniu, Dz. U. z dnia 29 października 2004 r, nr 236, poz. 2369.

(14) Urbaniak M.: Przeróbka i wykorzystanie osadów ze ścieków komunalnych. PAN, 1997, ss.80
(15) Wołoszyk Cz.: Agrochemiczna ocena nawożenia kompostami z komunalnych osadów ściekowych i odpadami przemysłowymi. Rozprawa nr 217. Wydaw. AR Szczecin, 2003, ss. 120. 